\title{
Thermal inactivation kinetics of partially purified mango pectin methylesterase
}

\author{
Claudio Alonso DÍAZ-CRUZ , Carlos REGALADO-GONZÁLEZ², Eduardo MORALES-SÁNCHEZ*,

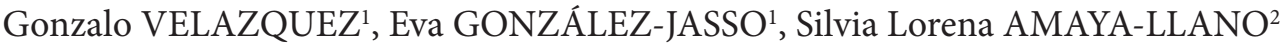

\begin{abstract}
Kinetic parameters of thermal inactivation of pectin methylesterase (PME) in a partially purified mango enzyme extract were determined. The PME of mango partially purified by salting out showed different patterns of thermal inactivation, indicating the presence of a thermostable fraction at $70^{\circ} \mathrm{C}$ and a thermolabile fraction at lower temperatures. The inactivation of the thermostable fraction exhibited a linear behavior that yielded a $\mathrm{z}$-value of $9.44^{\circ} \mathrm{C}$ and an activation energy (Ea) of $245.6 \mathrm{~kJ} \mathrm{~mol}^{-1} \mathrm{~K}^{-1}$ using the Arrhenius model. The thermostable mango PME fraction represented $17 \%$ of total crude enzyme extract, which emphasizes the importance of residual enzyme activity after heat treatment.
\end{abstract}

Keywords: thermal inactivation; pectin methylesterase; Ataulfo mango.

Practical application: In literature there is a lack of information about kinetic parameters describing the inactivation of pectin methylesterase in mango due mainly to the little or no activity of this enzyme in mango. This paper reports the kinetic of inactivation calculated from treatments at several times and temperatures. The information reported can serve as a reference when designing or applying heat treatments during pasteurization of fruit products.

\section{Introduction}

Turbidity and loss of consistency in fruit drinks are a common consequence of the activity of some endogenous enzymes or presence of microorganisms. This phenomenon can be a problem in processed product preservation (Castaldo et al., 1997). Within the enzyme systems present in the products obtained from fruit, is pectin methylesterase (PME, EC. 3.1.1.11), which belongs to the pectinesterase group. This enzyme catalyzes the hydrolysis of esterified groups of pectic substances, releasing methanol and forming precipitates by pectic acid interaction with calcium ions (Duvetter et al., 2009; Pilnik \& Voragen, 1991; Vercet et al., 1999; Whitaker, 1993). Therefore, it is necessary that PME is inactivated or inhibited properly to stabilize or maintain the turbidity of certain processed fruit products (Espachs-Barroso et al., 2006; Vercet et al., 1999). On the other hand, this enzyme is one of the most common used to determine the efficiency of fruit and vegetables blanching (Yemenicioglu \& Cemeroglu, 1988).

For fruit drinks and low-acid foods, thermal inactivation of enzymes involves the use of temperatures above $80^{\circ} \mathrm{C}$ (Ramesh, 2007) in heat pasteurization processes (Vercet et al., 1999). However, PME enzymes have been found that exhibit a wide thermal stability range in orange, acerola and carrot juices. This suggests the presence of thermostable and thermolabile fractions of PME isoenzyme complexes with irregular characteristics (Arbaisah et al., 1996; de Assis et al., 2000; Ly-Nguyen et al., 2003; Versteeg et al., 1980). In this regard, it should be noted that the technological problems in citrus juice associated with PME have been attributed to a high molecular weight thermostable fraction, which is also crucial in the establishment of pasteurization values in orange juice (Versteeg et al., 1980).

Several studies have reported a low enzyme activity in mango PME when compared to citruses and other fruits (Banjongsinsiri et al., 2004; Duvetter et al., 2009; Jamsazzadeh Kermani et al., 2015). Likewise, PME with different activities or characteristics has been reported in mango skin and pulp (Labib et al., 1995; Lizada, 1993). Additionally, the detection of mango PME inhibitors contributed to low levels of observed activity (Jamsazzadeh Kermani et al., 2015). Also, in studies with mango PME, kinetic inactivation parameters have been difficult to determine. In a study involving the analysis of Zebda variety mangos, PME thermal inactivation curves with irregular patterns were observed (Labib et al., 1995). Therefore, the objective of this study was to determine the kinetic parameters for thermal inactivation of PME from Ataulfo variety mango.

\section{Materials and methods}

\subsection{Materials}

Ripe Ataulfo mangoes in batches of $1.5 \mathrm{~kg}\left(17^{\circ} \mathrm{Bx}\right.$, $\mathrm{pH} 4.1 \pm 0.2$ ) were purchased in the local market at the end of spring. Apple pectin (degree of esterification 70-75\%) was obtained from Sigma-Aldrich and all used reagents were analytical grade.

${ }^{2}$ Programa de Posgrado en Alimentos del Centro de la República - PROPAC, Facultad de Química, Universidad Autónoma de Querétaro - UAQ, Centro Universitario Cerro de las Campanas, Querétaro, México

*Corresponding author: emoraless@ipn.mx 


\subsection{PME extraction}

The puree prepared from mango pulp was obtained using a commercial juicer (Jack Lalanne Power Juicer, USA) and was subsequently filtered using cheesecloth and the retained portion (bagasse) was used for PME extraction following the methodology described by Vercet et al. (1999) with some modifications. For PME extraction, mango bagasse was suspended in a mixture of borate acetate buffer (B-A) with a $\mathrm{pH}$ of 8.3 in a proportion of $1: 3$, ( $0.45 \mathrm{~mol} / \mathrm{L}$ boric acid, $0.1 \mathrm{~mol} / \mathrm{L}$ sodium tetraborate, $0.3 \mathrm{~mol} / \mathrm{L}$ sodium acetate and $0.2 \mathrm{~mol} / \mathrm{L} \mathrm{NaCl}$ ). The mixture was stirred for $4 \mathrm{~h}$ followed by a $12 \mathrm{~h}$ resting period at $4{ }^{\circ} \mathrm{C}$. The obtained extract was centrifuged at $3000 \mathrm{G}$ and the supernatant was dialyzed for $12 \mathrm{~h}$ using BA diluted 1:1000 to prevent further flocculation in the salting out. Subsequently, the supernatant was subjected to salting out by differential precipitation with ammonium sulfate at $30-80 \%$ saturation. The precipitate was then dissolved again using a $1: 3$ proportion in $1: 100 \mathrm{BA}$ solution containing $0.1 \mathrm{~mol} / \mathrm{L}$ $\mathrm{NaCl}$ and then dialyzed using a BA solution with a concentration of 1:1000. The resulting dialysate containing PME activity was considered pectin methylesterase crude extract (E-PME). The concentration of PMEs in fruits generally increases with maturity. In the case of mango, it has been reported that the PME activity increases as the fruit reaches $50 \%$ of its edible maturity and then decreases (Lizada, 1993). However in this study, the enzymatic activity of mango PME corresponded to a level five maturity with $15^{\circ} \mathrm{Bx}$ (Kader, 2015). Mangos at this level of maturity were used because this is the stage in which the fruit is commercialized.

\subsection{Determination of PME activity}

The PME activity was quantified by titration of the carboxyl groups liberated from the pectin using an automatic $\mathrm{pH}$-stat (Metrohm, Herisau, Switzerland). The quantification was carried out in triplicate. Modifications were made according to the method described by Kertesz (1955). The reaction mixture consisted of $10 \mathrm{ml}$ of a solution of apple pectin at $1 \%$ as substrate, $0.2 \mathrm{~mol} / \mathrm{L}$ $\mathrm{NaCl}$, and $0.1 \mathrm{~mol} / \mathrm{L} \mathrm{NaOH}$ was used in order to adjust the $\mathrm{pH}$ to 8 , taking into consideration the autodegradation of the pectin (Diaz et al., 2007; Renard \& Thibault, 1996). In addition to this $0.3 \mathrm{~mL}$ of E-PME was added, reducing the $\mathrm{pH}$ to 7.5. The $\mathrm{pH}$ was maintained at 7.5 by the addition of $0.01 \mathrm{~mol} / \mathrm{L}$ $\mathrm{NaOH}$ for $10 \mathrm{~min}$ at $30^{\circ} \mathrm{C}$. One unit of PME activity (UPME) was defined as the quantity of enzyme capable of releasing $1 \mathrm{mmol}$ of carboxyl groups / min (Balaban et al., 1991) and calculated according to Equation 1 (de Assis et al., 2000).

$\mathrm{UPME} / \mathrm{mL}=\frac{(\mathrm{mL} \text { of } \mathrm{NaOH})(\text { molarity of } \mathrm{NaOH})(1000)}{(\text { time })(\mathrm{mL} \text { of sample })}$

\subsection{Effect of $\mathrm{NaCl}$ and $\mathrm{pH}$ on PME activity}

The effect of sodium chloride on the E-PME activity was studied in the enzymatic reaction using different concentrations of $\mathrm{NaCl}(0.2,0.4,0.6,1.0$ and $1.5 \mathrm{~mol} / \mathrm{L})$ in pectin substrate. Likewise, the $\mathrm{pH}$ was varied within the same reaction (6.5, 7.0, and 7.5) to use for the measurement of activity during the subsequent experiments.

\subsection{Thermal inactivation of PME crude extract}

The dialyzed crude enzyme extract was treated using different times ( 0 to $40 \mathrm{~min}$ ) and temperatures $\left(64\right.$ to $78^{\circ} \mathrm{C}$ ) in thin-wall test tubes $(6 \mathrm{~mm}$ I.D.) placed in a water bath. The heating time was recorded for each sample until the desired temperature was reached. After treatment, the samples were immediately cooled using an ice water bath.

\subsection{Kinetic parameters}

The kinetic parameters for enzyme inactivation of mango PME were calculated using logarithmic reduction value (D) (Equation 2), the rate constant for inactivation (k) (Equation 3), the thermal resistance value constant $\mathrm{z}$ (Equation 4) described for a model of first-order inactivation well as the activation energy from the Arrhenius equation (Ea).

$\log a-\log b=\frac{t}{D}$

$\frac{b}{a}=e^{-k t}$

$\mathrm{z}=\frac{2.303 R T a^{2}}{E a}$

Where $a$ is the initial activity units, $b$ is the residual activity units at time $t, k$ is the inactivation constant, $R$ is the ideal gas constant $\left(\mathrm{kJ} \mathrm{mol}^{-1} \mathrm{~K}^{-1}\right), \mathrm{Ta}$ is the average of the experimental absolute reference temperature $(\mathrm{K})$ and $E a$ is the activation energy.

Obtained data was analyzed using ANOVA and the mean comparison was carried out by Tukey's test at $\mathrm{P}<0.05$.

\section{Results and discussion}

\subsection{Enzymatic mango extracts}

The crude extract obtained from Ataulfo variety mango bagasse pulp showed an enzyme activity of $52 \mathrm{UPME} / 100 \mathrm{~g}$ of wet pulp under the measurement conditions $(\mathrm{pH} 7.5$ and $0.2 \mathrm{~mol} / \mathrm{L} \mathrm{NaCl}, 30^{\circ} \mathrm{C}$ ). The enzymatic activity of this variety of mango was low and similar to Keitt variety mango puree where levels of activity up to $12.6 \pm 1.1 \mathrm{UPME} / \mathrm{g}$ have been reported (Banjongsinsiri et al., 2004; Jamsazzadeh Kermani et al., 2015). Low activity (4.5 UPME/100 g of pulp) was found in Zebda variety mango. However, it depends on the fruit tissue analyzed, where higher levels of activity were found in the skin when compared to the pulp by 8 -folds (Labib et al., 1995).

\subsection{Thermal inactivation of PME}

Thermal inactivation treatments of E-PME were carried out in a temperature range of 64 to $78{ }^{\circ} \mathrm{C}$ using a water bath. At this temperature range, the isothermal inactivation of $\mathrm{PME}$ showed different behaviors in the inactivation of the enzyme versus time. At temperatures below $70{ }^{\circ} \mathrm{C}$ nonlinear PME inactivation pattern was recorded and at temperatures above $70{ }^{\circ} \mathrm{C}$, a linear inactivation pattern was observed as described by a first order kinetic model for the inactivation of the enzyme 
(Figure 1). This suggests the presence of PME thermolabile and thermostable fractions. Such inactivation profile of PME has been reported also for orange, banana, and carrot extracts and is associated with the presence of isoenzymes (de Assis et al., 2000; Labib et al., 1995; Ly-Nguyen et al., 2003; Seymour et al., 1991; Vercet et al., 1999). On a technological level, the thermostable fractions are the most important factors used to determine the pasteurization values. For example, Versteeg et al. (1980) showed that 0.8 minutes at $90{ }^{\circ} \mathrm{C}$ is necessary to inactivate $99 \%$ of high molecular weight PME, which represents the thermostable fraction of navel orange PME.

In the transition between the two heat inactivation behaviors observed, at $68{ }^{\circ} \mathrm{C}$ biphasic inactivation is demonstrated. This behavior is due to the presence of two inactivation patterns, which are shown on the same plot (Figure 2). The first section of the curve is associated with the inactivation of the thermolabile fraction during the first $10 \mathrm{~min}$ of treatment. The second section of the curve is associated with the thermostable fraction, maintaining residual activity for at least $40 \mathrm{~min}$ after heat treatment (Figure 2). This biphasic behavior characteristic has also been described in orange (Seymour et al., 1991; Vercet et al., 1999) and carrot PME (Ly-Nguyen et al., 2003). In some published studies it has been implemented as a selective method for the inactivation of thermolabile PME isoenzymes (Ly-Nguyen et al., 2003; Seymour et al., 1991; Vercet et al., 1999).

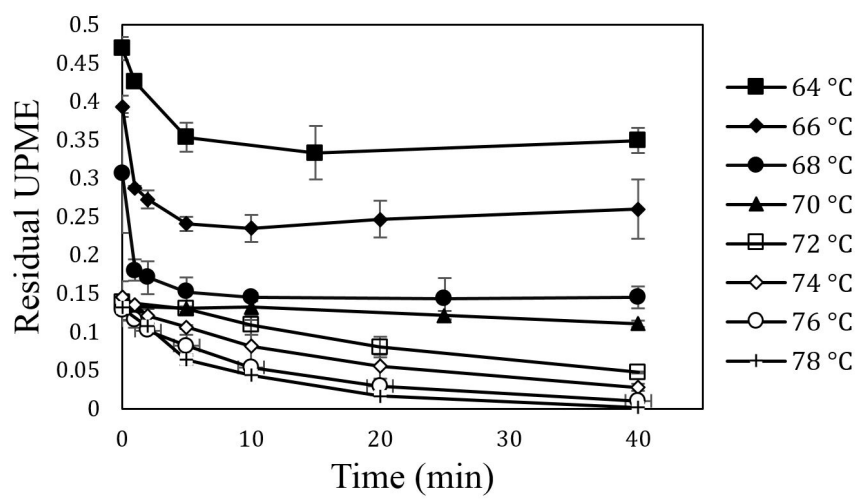

Figure 1. Thermal inactivation of mango E-PME.

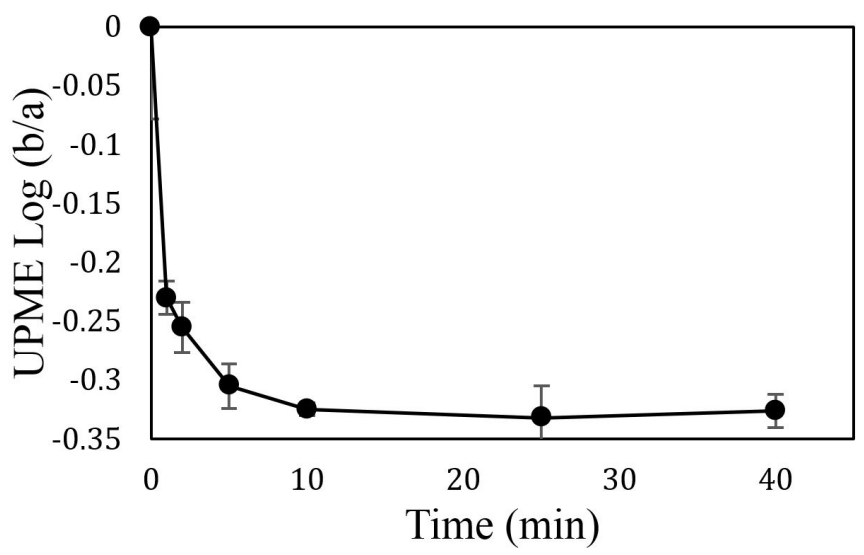

Figure 2. Thermal inactivation of mango E-PME at $68^{\circ} \mathrm{C}$.
Heat treatments at temperatures above $70{ }^{\circ} \mathrm{C}$, generally show linear patterns of E-PME inactivation (Figure 3), resulting in $\mathrm{D}$ values reported in Table 1, with low residual activities for the treatment times studied (17\% of the total residual activity). These low residual activity values correspond to those reported in the literature for different varieties of mango (Giovane et al., 1995; Jamsazzadeh Kermani et al., 2015).

The $\mathrm{z}$ value calculated in the temperature range from 72 to $78{ }^{\circ} \mathrm{C}$ for PME was $9.44^{\circ} \mathrm{C}$ obtained from the constants of inactivation using the Arrhenius equation (Table 1). This was a lower value than $18.5^{\circ} \mathrm{C}$ reported by Labib et al. (1995) who studied a different mango variety and different kinetics approach working with temperatures below $70^{\circ} \mathrm{C}$. The activation energy for thermal inactivation calculated using the Arrhenius equation (Hernández-Botello et al., 2014) (Figure 4) was $245.6 \mathrm{~kJ} \mathrm{~mol}^{-1} \mathrm{~K}^{-1}$, which could not be compared with other values due to the lack of information, however this value is similar to the values found in similar studies carried out with oranges (Duvetter et al., 2009).

Table 1. Calculated D and $\mathrm{k}$ values of Ataulfo mango.

\begin{tabular}{ccc}
\hline $\begin{array}{c}\text { Temperature } \\
\left({ }^{\circ} \mathrm{C}\right)\end{array}$ & $\begin{array}{c}\text { D value } \\
(\mathrm{min})\end{array}$ & $\begin{array}{c}\text { Inactivation constant } \\
(\mathrm{k})\end{array}$ \\
\hline 72 & $82.6 \pm 2.22^{\mathrm{a}}$ & $0.028 \pm 0.0007^{\mathrm{a}}$ \\
74 & $55.3 \pm 2.21^{\mathrm{b}}$ & $0.041 \pm 0.0016^{\mathrm{b}}$ \\
76 & $34.7 \pm 5.24^{\mathrm{c}}$ & $0.067 \pm 0.0103^{\mathrm{c}}$ \\
78 & $19.0 \pm 3.34^{\mathrm{d}}$ & $0.123 \pm 0.0217^{\mathrm{d}}$ \\
\hline
\end{tabular}

Different letters mean statistical significant difference $(\mathrm{p}<0.05)$.

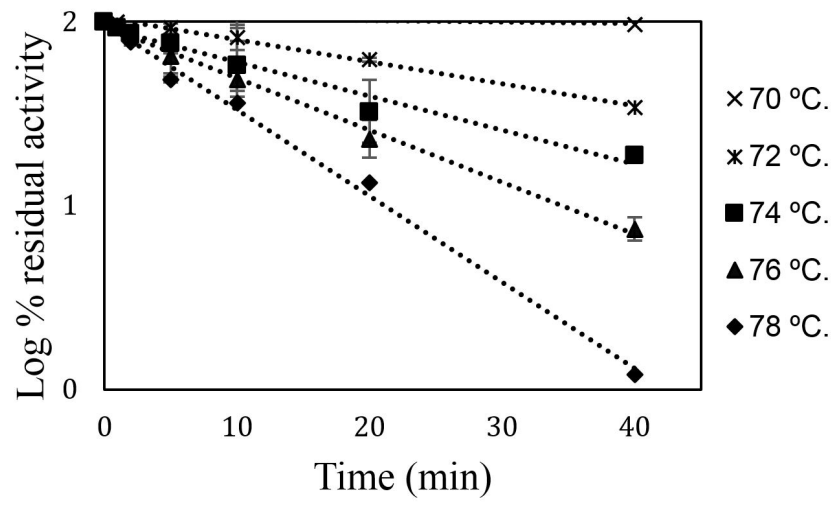

Figure 3. Inactivation of mango TME-PME.

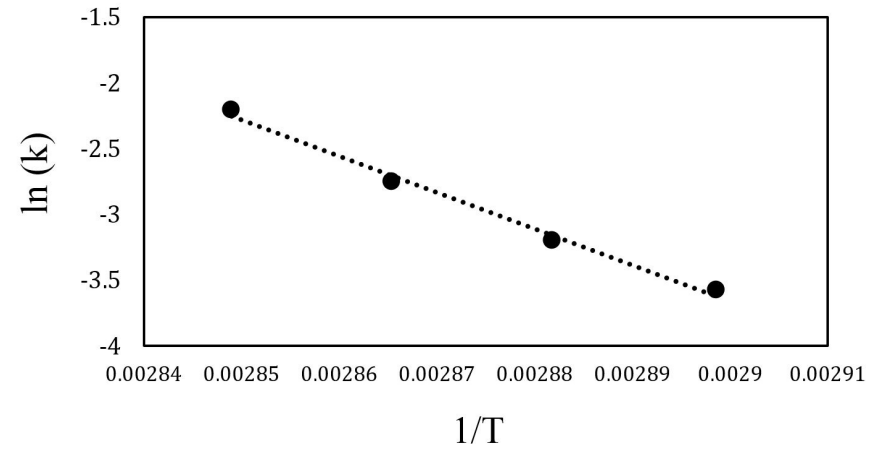

Figure 4. Arrhenius plot for inactivation of PME. 


\section{Conclusions}

In this study, two inactivation patterns of mango E-PME associated with the presence of different thermal stabilities were reported. Inactivation behavior described by a first order kinetic model for mango TME-PME fraction at temperatures above $70^{\circ} \mathrm{C}$ showed a linear inactivation pattern obtained with a z-value of $9.44^{\circ} \mathrm{C}$ in a temperature range of $72-78^{\circ} \mathrm{C}$. Results suggest the presence of minimal residual PME activity with a treatment time of $40 \mathrm{~min}$ at $78^{\circ} \mathrm{C}$ with a two logarithmic cycles inactivation reaching values near to complete inactivation. Likewise, the mango TME-PME fraction represented $17 \%$ of the total mango E-PME, an important percentage to take into account for conventional or alternative inactivation treatments.

\section{References}

Arbaisah, S. M., Asbi, B. A., Junainah, A. H., \& Jamilah, B. (1996). Determination of optimum conditions for pectinesterase extraction from soursop fruit (Anona muricata) using response surface methodology. Food Chemistry, 55(3), 289-292. http://dx.doi. org/10.1016/0308-8146(95)00105-0.

Balaban, M. O., Arreola, A. G., Marshall, M., Peplow, A., Wei, C. I., \& Cornell, J. (1991). Inactivation of pectinesterase in orange juice by supercritical carbon dioxide. Journal of Food Science, 56(3), 743-746. http://dx.doi.org/10.1111/j.1365-2621.1991.tb05372.x.

Banjongsinsiri, P., Kenney, S., \& Wicker, L. (2004). Texture and distribution of pectic substances of mango as affected by infusion of pectinmethylesterase and calcium. Journal of the Science of Food and Agriculture, 84(12), 1493-1499. http://dx.doi.org/10.1002/jsfa.1782.

Castaldo, D., Laratta, B., Loiudice, R., Giovane, A., Quagliuolo, L., \& Servillo, L. (1997). Presence of residual pectin methylesterase activity in thermally stabilized industrial fruit preparations. LWT - Food Science and Technology (Campinas), 30(5), 479-484. http://dx.doi. org/10.1006/fstl.1996.0211.

de Assis, S. A., Lima, D. C., \& de Faria Oliveira, O. M. M. (2000). Acerola’s pectin methylesterase: studies of heat inactivation. Food Chemistry, 71(4), 465-467. http://dx.doi.org/10.1016/S0308-8146(00)00173-4.

Diaz, J. V., Anthon, G. E., \& Barrett, D. M. (2007). Nonenzymatic degradation of citrus pectin and pectate during prolonged heating: effects of $\mathrm{pH}$, temperature, and degree of methyl esterification. Journal of Agricultural and Food Chemistry, 55(13), 5131-5136. http://dx.doi.org/10.1021/jf0701483. PMid:17550266.

Duvetter, T., Sila, D. N., Van Buggenhout, S., Jolie, R., Van Loey, A., \& Hendrickx, M. (2009). Pectins in processed fruit and vegetables: Part I-Stability and catalytic activity of pectinases. Comprehensive Reviews in Food Science and Food Safety, 8(2), 75-85. http://dx.doi. org/10.1111/j.1541-4337.2009.00070.x.

Espachs-Barroso, A., Van Loey, A., Hendrickx, M., \& Martín-Belloso, O. (2006). Inactivation of plant pectin methylesterase by thermal or high intensity pulsed electric field treatments. Innovative Food Science \& Emerging Technologies, 7(1-2), 40-48. http://dx.doi. org/10.1016/j.ifset.2005.07.002.

Giovane, A., Balestrieri, C., Quagliuolo, L., Castaldo, D., \& Servillo, L. (1995). A glycoprotein inhibitor of pectin methylesterase in kiwi fruit. Purification by affinity chromatography and evidence of a ripening-related precursor. European Journal of Biochemistry, 233(3), 926-929. http://dx.doi.org/10.1111/j.1432-1033.1995.926_3.x. PMid:8521860.
Hernández-Botello, M. T, Chanona-Pérez, J. J., Mendoza-Pérez, J. A., Trejo-Valdez, M., Calderón-Domínguez, G., Barriada Pereira, J. L., Sastre de Vicente, M. E., Perea-Flores, M. J., \& Terres-Rojas, E. (2014). Effect of the fluidized bed drying on the structure and biosorption capability of $\mathrm{Pb}+2$ of agave epidermis. Revista Mexicana de Ingeniería Química, 13(3), 865-885.

Jamsazzadeh Kermani, Z., Shpigelman, A., Houben, K., ten Geuzendam, B., Van Loey, A. M., \& Hendrickx, M. E. (2015). Study of mango endogenous pectinases as a tool to engineer mango purée consistency. Food Chemistry, 172, 272-282. http://dx.doi.org/10.1016/j. foodchem.2014.09.077. PMid:25442554.

Kader, A. A. (2015). Mango: Recommendations for maintaining postharvest Quality. Retrieved from http://postharvest.ucdavis. edu/PFfruits/Mango/

Kertesz, Z. I. (1955). Pectic enzymes. In S. P. Colowick \& N. O. Kalpan (Eds.), Methods in enzymology (Vol. 1, pp. 158-162). New York: Academic Press.

Labib, A. A. S., El-Ashwah, F. A., Omran, H. T., \& Askar, A. (1995). Heat-inactivation of mango pectinesterase and polygalacturonase. Food Chemistry, 53(2), 137-142. http://dx.doi.org/10.1016/03088146(95)90778-6.

Lizada, C. (1993). Mango. In G. B. Seymour, J. E. Taylor \& G. A. Tucker (Eds.), Biochemistry of fruit ripening (pp. 255-271). Springer Netherlands. http://dx.doi.org/10.1007/978-94-011-1584-1_8.

Ly-Nguyen, B., Loey, A. M., Smout, C., ErenOzcan, S., Fachin, D., Verlent, I., Truong, S. V., Duvetter, T., \& Hendrickx, M. E. (2003). Mild-heat and high-pressure inactivation of carrot pectin methylesterase: a kinetic study. Journal of Food Science, 68(4), 1377-1383. http:// dx.doi.org/10.1111/j.1365-2621.2003.tb09653.x.

Pilnik, W., \& Voragen, A. G. J. (1991). The significance of endogenous and exogenous pectic enzymes in fruit and vegetable processing In P. F. Fox (Ed.), Food enzymology (Vol. 1, pp. 303-336). London/New York: Elsevier Applied Science.

Ramesh, M. N. (2007). Pasteurization and food preservation. In M. S. Rahman (Ed.), Handbook of food preservation (2nd ed., pp. 571-583). Boca Raton: CRC Press. http://dx.doi.org/10.1201/9781420017373.pt4.

Renard, C. M. G. C., \& Thibault, J.-F. (1996). Degradation of pectins in alkaline conditions: kinetics of demethylation. Carbohydrate Research, 286, 139-150. http://dx.doi.org/10.1016/0008-6215(96)00056-0.

Seymour, T. A., Preston, J. F., Wicker, L., Lindsay, J. A., \& Marshall, M. R. (1991). Purification and properties of pectinesterases of Marsh white grapefruit pulp. Journal of Agricultural and Food Chemistry, 39(6), 1080-1085. http://dx.doi.org/10.1021/jf00006a015.

Vercet, A., Lopez, P., \& Burgos, J. (1999). Inactivation of heat-resistant pectinmethylesterase from orange by manothermosonication. Journal of Agricultural and Food Chemistry, 47(2), 432-437. http://dx.doi. org/10.1021/jf980566v. PMid:10563912.

Versteeg, C., Rombouts, F. M., Spaansen, C. H., \& Pilnik, W. (1980). Thermostability and orange juice cloud destabilizing properties of multiple pectinesterases from orange. Journal of Food Science, 45(4), 969-971. http://dx.doi.org/10.1111/j.1365-2621.1980.tb07489.x.

Whitaker, J. R. (1993). Principles of enzymology for the food sciences (Food Science and Technoloy, Vol. 61). New York: CRC Press.

Yemenicioglu, A., \& Cemeroglu, B. (1988). Determination of the activity of enzymes used as indicator in heat treatment. Gida Teknolojisi (Food Technology), 9(3), 76-80. 